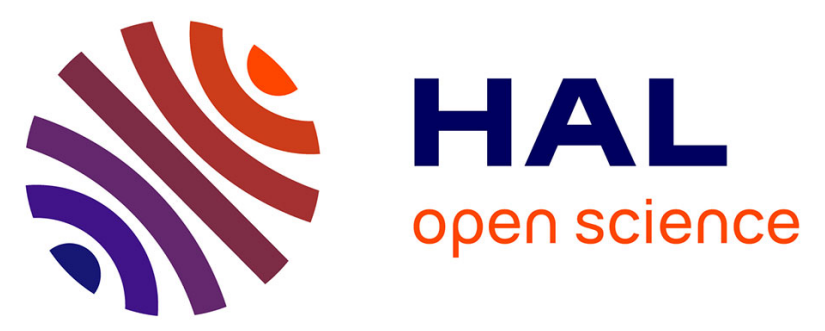

\title{
Which method of adherence measurement is most suitable for daily use to predict virological failure among immigrant and non-immigrant HIV-1 infected patients?
}

Jeannine Francisca Nellen, P Nieuwkerk, David M Burger, Mirte Wibaut, Luuk A Gras, Jan M Prins

\section{To cite this version:}

Jeannine Francisca Nellen, P Nieuwkerk, David M Burger, Mirte Wibaut, Luuk A Gras, et al.. Which method of adherence measurement is most suitable for daily use to predict virological failure among immigrant and non-immigrant HIV-1 infected patients?. AIDS Care, 2009, 21 (07), pp.842-850. 10.1080/09540120802612816 . hal-00513479

\author{
HAL Id: hal-00513479 \\ https://hal.science/hal-00513479
}

Submitted on 1 Sep 2010

HAL is a multi-disciplinary open access archive for the deposit and dissemination of scientific research documents, whether they are published or not. The documents may come from teaching and research institutions in France or abroad, or from public or private research centers.
L'archive ouverte pluridisciplinaire HAL, est destinée au dépôt et à la diffusion de documents scientifiques de niveau recherche, publiés ou non, émanant des établissements d'enseignement et de recherche français ou étrangers, des laboratoires publics ou privés. 

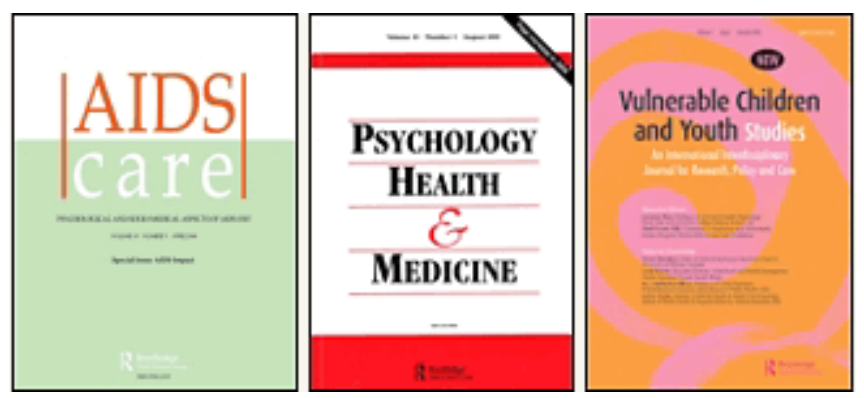

Which method of adherence measurement is most suitable for daily use to predict virological failure among immigrant and non-immigrant HIV-1 infected patients?

\begin{tabular}{|r|l|}
\hline Journal: & $\begin{array}{l}\text { AIDS Care - Psychology, Health \& Medicine - Vulnerable Children } \\
\text { and Youth Studies }\end{array}$ \\
\hline Manuscript ID: & AC-2008-03-0136.R2 \\
\hline Journal Selection: & AIDS Care \\
\hline Keywords: & Antiretroviral Therapy, Adherence, Migrants \\
\hline
\end{tabular}

\section{ScholaroNE" \\ Manuscript Central}


Which method of adherence measurement is most suitable for daily use to predict virological failure among immigrant and non-immigrant HIV-1 infected patients?

\begin{abstract}
In industrialized countries, virological failure occurs more often among HIV-infected immigrant patients. Non-adherence is the most credible explanation. We compared adherence of immigrant patients with that of non-immigrant patients in the Netherlands, and investigated which method of adherence measurement is most suitable for daily use to predict virological treatment failure: testing knowledge of the current regimen, a quantitative adherence interview, pharmacy prescription refill ratio (dispensed medication divided by prescribed medication, DM/PM), and plasma drug levels. Included were 61 immigrants and 81 nonimmigrants. Virological failure did occur more often in immigrants than in non-immigrants (19.7\% (12/61) versus $8.6 \%(7 / 81), \mathrm{p}=0.056)$, especially among previously naïve patients $(19.6 \%(11 / 56)$ versus $0 \%(0 / 54), \mathrm{p}<0.01)$. There were no differences between both groups on any of the four adherence measures. Virological failure was associated with reporting stopping medication when not feeling well (OR 12, 95\%CI 1.9-77.7, p=0.02), and, among naive patients, also with a DM/PM $<0.85$ (OR 5.1, 95\%CI 1.2-22.3, $\mathrm{p}=0.03$ ). Although our study confirmed a much higher virological failure rate among immigrants, we were unable to identify clear differences in adherence between immigrants and non-immigrant patient, although virological failure was associated with stopping medication when not feeling well and a low DM/PM. Unstructured treatment interruptions are a likely explanation of the findings. Interventions should be aimed at preventing patients to stop medication. A DM/PM below 0.85 can be indicative for patients who did stop medication and are at risk for virological failure.
\end{abstract}




\section{INTRODUCTION}

In the Netherlands and other industrialized countries, HIV infected patients comprise a highly diverse group, ranging from highly educated, male homosexuals to illiterate, unemployed, heterosexually infected female refugees from Africa. In the Netherlands and France, virological failure during HAART occurs more often in immigrants than among nonimmigrants (Nellen et al., 2004; van den Berg et al., 2005; Dray-Spira, Spire, Heard, \& Lert, 2007). A credible explanation for this finding consists of lower levels of adherence in the immigrant group. Known risk factors for lower levels of adherence such as young age, low socio-economic status and low perceived social support are more prevalent among immigrants (Ammassari et al., 2002). Biological factors such as viral subtype, pharmacokinetics or genetic factors do not convincingly explain differences in therapy success between immigrants and non-immigrants (Bocket et al., 2005; de Maat et al., 2004; Johnson, 1997; Kaslow \& McNicholl, 1999; Schaeffeler et al., 2001).

High levels of adherence to HAART are crucial for achieving and maintaining viral suppression (Paterson et al., 2000; Bangsberg, 2006). However, adherence is difficult to objectify due to lack of a gold standard (de, Hospers, van den Borne, Kok, \& Prins, 2005; Yuan, L'italien, Mukherjee, \& Iloeje, 2006; Kleeberger et al., 2001).

Goal of the study was to compare adherence between HIV-1 infected immigrants and nonimmigrants in the Netherlands, and to identify which method of adherence measurement was most suitable for daily use to predict virological failure. We used different validated markers of adherence: knowledge of the current regimen (Parienti et al., 2001), a quantitative interview regarding adherence (Nieuwkerk, Gisolf, Sprangers, \& Danner, 2001; Nieuwkerk et al., 2001; Nieuwkerk \& Oort, 2005), pharmacy prescription refills (Gross et al., 2006) and plasma drug levels (Liechty et al., 2004). 


\section{METHODS}

At the start of the study in Januari 2003, the HIV outpatient clinic of the Academic Medical Center, University of Amsterdam, had 1368 patients in care of which 998 (73\%) were males and $703(51 \%)$ were indigenous Dutch. The largest groups of immigrant patients were from sub-Saharan Africa $(237,17 \%)$ and the former Dutch colonies Surinam and the Netherlands Antilles (140, $10 \%)$.

Patients were eligible for the study when they were HIV-1 infected, on HAART for more than 14 days, originating from the Netherlands (non-immigrants), or the mentioned countries (immigrants). Patients were recruited by their treating physician when visiting the outpatient clinic for a scheduled visit. Treating physicians approached consecutive eligible patients only on days when an interviewer for the current study was present. Patients were interviewed directly after their consultation. The Medical Ethical Committee of our hospital approved this study.

Virological failure was defined as a plasma HIV-1 RNA concentration above 400 copies/mL while still on HAART, at any time from 6 months after the initiation of HAART until 2 years after the adherence interview. Data about virological treatment response were retrieved from the Netherlands ATHENA observational cohort database. Data are collected prospectively after a patient enters the cohort. Data prior to inclusion in the cohort are collected retrospectively (van Sighem et al., 2003).

Three trained interviewers, who were not involved in patient care, assessed knowledge of the current regimen and treatment adherence during an interview. Consenting patients were asked to identify their prescribed pills in a box containing all available antiretroviral medication, and to indicate the amount and frequency they were expected to take the selected medication. Next, a quantitative interview on adherence was completed (Table 1). We calculated a global 
adherence score by defining patients who reported either taking medication too late yesterday or the day before yesterday, to miss medication, reporting to stop medication when feeling well or when not feeling well or to take medication later than prescribed as non-adherent.

Patients were also asked to report the number of scheduled outpatient clinic visits they had missed in the last year. This number was compared with the number of actually missed appointments according to the hospital registration system.

In our hospital, plasma drug level measurement is part of routine patient care. Plasma drug levels were retrieved from the clinical case notes. The plasma drug level closest to the interview date was selected. For protease inhibitors (PI's) a drug level consistent with nonadherence was defined as a concentration ratio (CR) below 0.25 (Burger et al., 1998; Burger et al., 2003). For the non-nucleoside reverse transcriptase inhibitors (NNRTI's) nonadherence was assumed in case of a plasma drug concentration below $25 \%$ of the minimal effective concentration, resulting in a cut-off for efavirenz plasma concentrations of 0.25 mg/L (Marzolini et al., 2001), and for nevirapine plasma concentrations of $0.8 \mathrm{mg} / \mathrm{L}$ (de Vries-Sluijs et al., 2003).

Data on dispensation of medication by the pharmacy were retrieved from pharmacy reports: respondents were asked for the name of their pharmacy. After the interview we requested this pharmacy for information about dispensed medication in the past six months. The ratio of dispensed medication divided by prescribed medication (DM/PM) was calculated for each patient. Non-adherence was defined as a ratio of $<0.85$ (Grossberg, Zhang, \& Gross, 2004). Because the DM/PM was based on retrospective pharmacy reports over a single period of time, and data on medication stockpiles at home from previous prescriptions was not available, a 0.95 cut-off seemed too strict (Gross et al., 2006).

Categorical data were compared using Chi-square or Fishers' Exact-Tests where appropriate. 
Mann-Whitney U-tests were used to compare continuous variables. We calculated odds ratios for non-adherence in the immigrant group compared to the non-immigrant group, and odds ratios for virological failure in case of non-adherence as defined by each of the above described adherence measurements, irrespective of patient group. If one cell in the $2 \times 2$ table was empty we added 0.5 to all four cell frequencies in the table. All reported P-values are two-sided. Differences between groups were considered significant at $\mathrm{P}<0.05$. 


\section{RESULTS}

Our analyses included 142 HIV-positive patients: 61 immigrants (Sub-Saharan African patients $n=44$; Surinam and Netherlands Antillean patients $n=17$ ) and 81 non-immigrants. Baseline characteristics are given in table 2. Immigrants were significantly more often female, younger, heterosexually infected, had a lower highest plasma viral load, a shorter time since HIV-diagnosis, and a lower number of previous HAART regimens than non-immigrants, reflecting existing and previously described differences between patient groups at our clinic. (Nellen et al., 2004).

Virological failure within 2 years after the interview occurred in 12/61 immigrants (19.7\%) and in 7/81 non-immigrants $(8.6 \%)$, OR 2.6, 95\% CI 1.0-7.0, p=0.056. Pre-treated were 32 patients with non-HAART regimens of which $5(8.2 \%)$ were immigrants and $27(33.3 \%)$ were non-immigrants, $\mathrm{p}<0.01$. When only patients who started HAART being antiretroviral naïve were considered, $19.6 \%(11 / 56)$ of the immigrants experienced virological failure (10 female, 1 male) compared with none (0/54) of the non-immigrants (OR 27.5, 95\%CI 1.6-480, $\mathrm{p}<0.01)$

Results of the adherence measurements in non-immigrants and immigrants, the odds for nonadherence in immigrants and the odds for experiencing virological failure in case of suboptimal adherence are given in table 3 .

Both non-immigrants and immigrants showed remarkably good knowledge of their HAART regimen, with only $6.3 \%$ and $3.6 \%$ demonstrating incorrect knowledge, respectively. There was no association between incorrect knowledge of the regimen and virological failure.

Immigrants judged their HAART regimen significantly more often as neutral to very difficult, but this was not related with virological failure. Reported difficulties included mainly sideeffects (fatigue, weight gain, nausea, bad taste) and the confrontation with being HIV-infected 
when taking medication. Other complaints were size of the tablets, the need for getting up early in weekends for the medication, and taking medication with food. Once daily one tablet was often mentioned as a potential improvement. There were no clear differences in reported difficulties between the groups.

There was only one significant difference in self-reported adherence: non-immigrants admitted significantly more often to take the medication too late the day before yesterday, but this was not related to virological failure. The only question from the interview associated with virological failure was admitting to stop with the medication when not feeling well, for example due to side effects of the medication. $3 / 5(60 \%)$ of the patients admitting to stop medication when not feeling well experienced virological failure compared with 15/135 $(11.1 \%)$ of the patients not admitting to stop medication $(\mathrm{p}=0.02)$. This association remained after exclusion of the pre-treated patients: OR 24.3, 95\%CI 2.0-297, $\mathrm{p}=0.02$. We observed no difference between both groups on the global adherence score, nor was the global adherence score associated with virological failure.

Although there was no difference between the two groups in reporting having missed a clinic visit, significantly more immigrants, i.e., 30 out of 61 (49\%), had actually missed visits during the last year according to the hospital registration system compared with non-immigrants, i.e., 25 out of $79(31.6 \%)(\mathrm{p}=0.04)$. Immigrants also had a significantly higher number of missed visits than non-immigrants (mean 0.92 , SD 1.3 versus 0.32 , SD 0.7, $\mathrm{p}=0.008$ ). Missing appointments was not significantly associated with virological failure.

There were 136 plasma drug levels available. The median time between the measurement and the interview date was 0 days (IQR $-4.0-+27.3$ ). The percentage of drug levels compatible with non-adherence was higher among immigrants although not statistically significant: $4 \%$ (3/75) among non-immigrants (3 efavirenz) versus $11.5 \%$ (7/ 61) among immigrants (1 efavirenz, 3 lopinavir, 3 nelfinavir) ( $\mathrm{p}=0.11$ ). Low plasma drug levels were not associated 
with virological failure: 2/10 (20\%) of patients with low drug levels experienced virological failure compared 17/126 (13.5\%) of patients with drug levels not considered to be too low.

For $115 / 142$ patients a DM/PM could be calculated. The missing data were due to interviewers who did not ask the question about the pharmacy or patients who could not name their pharmacy. None of the patients reported buying medications in more than one pharmacy. The ratio DM/PM was not different between groups. The median ratio in non-immigrants was 0.97, (IQR 0.70-0.99) and in immigrants 0.99 (IQR 0.82-1.07), $\mathrm{p}=0.17$. A DM/PM $<0.85$ was close to significance associated with virological failure. $8 / 38(21.1 \%)$ of patients with $\mathrm{DM} / \mathrm{PM}<0.85$ had virological treatment failure compared with $7 / 77(9.1 \%)$ of patients with $\mathrm{DM} / \mathrm{PM}>0.085(\mathrm{p}=0.09)$. When only antiretroviral naïve patients were considered, a low $\mathrm{DM} / \mathrm{PM}$ was significantly associated with virological failure: OR 5.1 (95\%CI 1.2-22.3, $\mathrm{p}=0.03)$. A DM/PM $<0.85$ was associated for the whole group with the questions "Do you ever miss medication" (OR 3.5, 95\% CI 1.5-8.1, p<0.01) and "Do you ever take the medication later than prescribed" (OR 3.0, 95\%CI 1.3-6.9, p=0.01). A DM/PM $<0.85$ was also associated with both questions when pre-treated patients were excluded: OR 3.1 (95\%CI 1.2-7.9, $\mathrm{p}=0.02)$ for ever missing the medication and $\mathrm{OR} 3.2(95 \% \mathrm{CI} 1.2-8.3, \mathrm{p}=0.02)$ for ever taking the medication too late. 


\section{DISCUSSION}

In our study, immigrant patients had significantly higher virological failure rates than nonimmigrants. We were unable to identify clear differences in adherence using validated markers. The only validated marker for non-adherence associated with virological failure was reporting to stop with medication when not feeling well. After exclusion of pre-treated patients, patients with a DM/PM below 0.85 were also more likely to experience virological failure. The patients with virological failure, mostly immigrant females, had theoretically similar access to care. Their regimen knowledge, self-reported adherence, plasma drug levels and pharmacy refill reports did not show any difference explaining the poorer treatment results.

Knowledge of the regimen was high in both groups compared to the literature (Wolf et al., 2005; Stone et al., 2001). A lower level of literacy and poor medication knowledge are associated with lower adherence, but there was no suggestion at all that immigrants had poor regimen knowledge despite the (perceived) lower level of literacy (Kalichman, Ramachandran, \& Catz, 1999; Miller et al., 2003).

Immigrant patients perceived their regimen as more difficult, but this was not associated with virological failure. This could be explained by the fact that non-immigrants had a longer duration of HAART and a higher number of previous HAART regimens. The earlier HAART regimens were more complex, so this could bias the judgement of non-immigrants of their current regimen.

Immigrants reported similar or even better adherence in spite of the higher virological failure rates. To date, little is known about the validity of self-reported adherence among immigrant or migrant populations. Self-reports may be biased due to cultural differences between interviewer and patient or language problems. Marcellin et al. found no evidence of more 
biased self-reports in immigrant French patients. In our study, the two groups differed only for the question "Did you take the medication on time the day before yesterday": immigrants reported significantly better adherence on this question. Reported missed clinic visits in both patient groups were similar, but actual missed visits did occur more often in immigrants. These two findings suggest that immigrants did show a tendency to answer more socially desirable, which would make self-reported adherence less reliable.

Reporting to stop medication when not feeling well was associated with virological failure, which is in accordance with previous studies: medication side effects are a well known risk factor for non-adherence (Ammassari et al., 2002).

Immigrants had significantly more often a missed clinic visit, but this was not associated with virological failure as shown before (Lucas, Chaisson, \& Moore, 1999; Park et al., 2007). So missing a clinic visit did not necessarily suggest non-adherence in our patient group. This is consistent with findings from a French cohort, where missed visits among migrants were unrelated with adherence, whereas missed visits among native French persons were related with lower levels of adherence (Carrieri et al., 2001).

Plasma drug levels were not associated with non-adherence among immigrants. Therapeutic drug monitoring is proven valuable to identify patients at risk for virological failure, but especially for patients on unboosted PI's, whereas our patients were mainly on NNRTI's, (Hugen et al., 2002; Burger et al., 2003; Oette et al., 2006). The cut-off values for nonadherence were stringent, to be sure of non-adherence. We cannot exclude they were too strict, as can be suggested by the low numbers of low plasma drug levels.

There was no difference between groups in DM/PM, but it was close to significant associated with virological failure and significantly associated with virological failure after exclusion of pretreated patients. This low DM/PM correlated well with two items from the interview: reporting to miss medication and reporting to take medication too late. 
Our sample size was in the range of the individual caseload of an HIV physician and we used methods detecting non-adherence as used in current patient care. The risk for virological failure was higher for the immigrants, showing that we probably investigated a representative patient sample. One can conclude that the methods used to measure adherence had not enough sensitivity or that immigrants have a similar adherence. However, there is no plausible explanation for the higher rate of virological failure among immigrants besides lower adherence. Lower adherence was previously documented in immigrant populations (Mannheimer, Friedland, Matts, Child, \& Chesney, 2002). Unstructured treatment interruptions are a likely explanation of the findings: these are only identified by the DM/PM.

Immigrant patients in the current study had low rates of advanced HIV disease. We found a similar low rate of advanced HIV disease among immigrants in a previous study which included the entire patient population from our outpatient clinic (Nellen et al., 2004). Consequently, we believe this low rate of advanced disease reflects a characteristic of our patient population rather than a form of selection bias.

Immigrants had lower plasma HIV-RNA levels than non-immigrants. This is likely explained by the higher percentage of black females in the immigrant group. HIV infected females and black patients generally have lower viral loads at given CD4 cell counts (Saul, Erwin, Sabin, Kulasegaram, \& Peters, 2001; Smith et al., 2003).

Our study had several limitations. Immigrant patients had a shorter duration of HAART and time since HIV diagnoses than non-immigrants. However, we adjusted our results for this difference by repeating the analysis after excluding patients who had received antiretroviral therapy prior to initiation of HAART as these were the patients with the longest time since HIV diagnoses and time since start of HAART.

We were unable to consider viral load at a fixed time point after the adherence interview for 
the analysis of virological failure. Potentially, our results could be biased due to more frequent viral load assessments for some individuals. Our study was conducted in daily clinical practice, in which one can not ignore signs of non-adherence or potential virological failure necessitating plasma viral load measurement before a fixed time point. We believe it is unlikely this has biased our results, because the rates of virological failure among immigrants and non-immigrants were comparable to those that we previously found among the entire population of patients attending our outpatient clinic (Nellen et al., 2004).

We did not collect data on patients who refused to participate. Consequently, we were unable to compare characteristics between patients who did and who did not participate in the study. Because baseline characteristics and virological failure rates are in accordance with known baseline characteristics and virological failure rates of our outpatient clinic, we believe we included a representative group of patients in the current study.

Our study had a low sample size. The number of patients with poor adherence was consequently even smaller. Therefore, the results of this study should be interpreted with caution, especially results on the association between adherence and virological failure.

For the moment we suggest that immigrants are monitored and supported more intensely than non-immigrants also after having reached an undetectable viral load, because of their higher risk of virological failure. Patients should be instructed with great emphasis not to stop medication when not feeling well and their physicians should take complaints of side-effects seriously, because they may jeopardize adherence. The calculation of DM/PM can easily be incorporated in patient care and when combined with an alert to the care provider when medication is not collected or collected too late, interventions can take place before virological failure happens. Future studies should evaluate this method which can measure adherence on a continuous basis without inconvenience for the patient. 


\section{Reference List}

Ammassari, A., Trotta, M. P., Murri, R., Castelli, F., Narciso, P., Noto, P. et al. (2002). Correlates and predictors of adherence to highly active antiretroviral therapy: overview of published literature. J.Acquir.Immune.Defic.Syndr., 31 Suppl 3, S123-S127.

Bangsberg, D. R. (2006). Less than $95 \%$ adherence to nonnucleoside reversetranscriptase inhibitor therapy can lead to viral suppression. Clin.Infect.Dis., 43, 939-941.

Bocket, L., Cheret, A., Deuffic-Burban, S., Choisy, P., Gerard, Y., de, 1. Tribonniere, $\mathrm{X}$ et al. (2005). Impact of human immunodeficiency virus type 1 subtype on first-line antiretroviral therapy effectiveness. Antivir.Ther., 10, 247-254.

Burger, D. M., Hoetelmans, R. M., Hugen, P. W., Mulder, J. W., Meenhorst, P. L., Koopmans, P. P. et al. (1998). Low plasma concentrations of indinavir are related to virological treatment failure in HIV-1-infected patients on indinavir-containing triple therapy. Antivir.Ther., 3, 215-220.

Burger, D. M., Hugen, P. W., Aarnoutse, R. E., Hoetelmans, R. M., Jambroes, M., Nieuwkerk, P. T. et al. (2003). Treatment failure of nelfinavir-containing triple therapy can largely be explained by low nelfinavir plasma concentrations. Ther.Drug Monit., 25, 73-80.

Carrieri, P., Cailleton, V., Le Moing, V, Spire, B., Dellamonica, P., Bouvet, E. et al. (2001). The dynamic of adherence to highly active antiretroviral therapy: results from the French National APROCO cohort. J.Acquir.Immune.Defic.Syndr., 28, 232-239.

de Maat, M. M., Nellen, J. F., Huitema, A. D., Wit, F. W., Mulder, J. W., Prins, J. M. et al. (2004). Race is not associated with nevirapine pharmacokinetics. Ther.Drug Monit., 26, 456-458.

de Vries-Sluijs, T. E., Dieleman, J. P., Arts, D., Huitema, A. D., Beijnen, J. H., Schutten, M. et al. (2003). Low nevirapine plasma concentrations predict virological failure in 
an unselected HIV-1-infected population. Clin.Pharmacokinet., 42, 599-605.

de Bruin, M., Hospers, H. J., van den Borne, H. W., Kok, G., \& Prins, J. M. (2005). Theory- and evidence-based intervention to improve adherence to antiretroviral therapy among HIV-infected patients in the Netherlands: a pilot study. AIDS Patient.Care STDS., 19, 384-394.

Dray-Spira, R., Spire, B., Heard, I., \& Lert, F. (2007). Heterogeneous response to HAART across a diverse population of people living with HIV: results from the ANRSEN12-VESPA Study. AIDS, 21 Suppl 1, S5-12.

Gross, R., Yip, B., Lo Re V., III, Wood, E., Alexander, C. S., Harrigan, P. R. et al. (2006). A simple, dynamic measure of antiretroviral therapy adherence predicts failure to maintain HIV-1 suppression. J.Infect.Dis., 194, 1108-1114.

Grossberg, R., Zhang, Y., \& Gross, R. (2004). A time-to-prescription-refill measure of antiretroviral adherence predicted changes in viral load in HIV. J.Clin.Epidemiol., 57, 11071110.

Hugen, P. W., Burger, D. M., Aarnoutse, R. E., Baede, P. A., Nieuwkerk, P. T., Koopmans, P. P. et al. (2002). Therapeutic drug monitoring of HIV-protease inhibitors to assess noncompliance. Ther.Drug Monit., 24, 579-587.

Johnson, J. A. (1997). Influence of race or ethnicity on pharmacokinetics of drugs. J.Pharm.Sci., 86, 1328-1333.

Kalichman, S. C., Ramachandran, B., \& Catz, S. (1999). Adherence to combination antiretroviral therapies in HIV patients of low health literacy. J.Gen.Intern.Med., 14, 267-273.

Kaslow, R. A. \& McNicholl, J. M. (1999). Genetic determinants of HIV-1 infection and its manifestations. Proc.Assoc.Am.Physicians, 111, 299-307.

Kleeberger, C. A., Phair, J. P., Strathdee, S. A., Detels, R., Kingsley, L., \& Jacobson, 
L. P. (2001). Determinants of heterogeneous adherence to HIV-antiretroviral therapies in the Multicenter AIDS Cohort Study. J.Acquir.Immune.Defic.Syndr., 26, 82-92.

Liechty, C. A., Alexander, C. S., Harrigan, P. R., Guzman, J. D., Charlebois, E. D., Moss, A. R. et al. (2004). Are untimed antiretroviral drug levels useful predictors of adherence behavior? AIDS, 18, 127-129.

Lucas, G. M., Chaisson, R. E., \& Moore, R. D. (1999). Highly active antiretroviral therapy in a large urban clinic: risk factors for virologic failure and adverse drug reactions. Ann.Intern.Med., 131, 81-87.

Mannheimer, S., Friedland, G., Matts, J., Child, C., \& Chesney, M. (2002). The consistency of adherence to antiretroviral therapy predicts biologic outcomes for human immunodeficiency virus-infected persons in clinical trials. Clin.Infect.Dis., 34, 1115-1121.

Marzolini, C., Telenti, A., Decosterd, L. A., Greub, G., Biollaz, J., \& Buclin, T. (2001). Efavirenz plasma levels can predict treatment failure and central nervous system side effects in HIV-1-infected patients. AIDS, 15, 71-75.

Miller, L. G., Liu, H., Hays, R. D., Golin, C. E., Ye, Z., Beck, C. K. et al. (2003). Knowledge of antiretroviral regimen dosing and adherence: a longitudinal study. Clin.Infect.Dis., 36, 514-518.

Nellen, J. F., Wit, F. W., de Wolf, F., Jurriaans, S., Lange, J. M., \& Prins, J. M. (2004). Virologic and Immunologic Response to Highly Active Antiretroviral Therapy in Indigenous and Nonindigenous HIV-1-Infected Patients in The Netherlands. J.Acquir.Immune.Defic.Syndr., 36, 943-950.

Nieuwkerk, P., Gisolf, E., Sprangers, M., \& Danner, S. (2001). Adherence over 48 weeks in an antiretroviral clinical trial: variable within patients, affected by toxicities and independently predictive of virological response. Antivir.Ther., 6, 97-103.

Nieuwkerk, P. T. \& Oort, F. J. (2005). Self-Reported Adherence to Antiretroviral 
Therapy for HIV-1 Infection and Virologic Treatment Response: A Meta-Analysis. J.Acquir.Immune.Defic.Syndr., 38, 445-448.

Nieuwkerk, P. T., Sprangers, M. A., Burger, D. M., Hoetelmans, R. M., Hugen, P. W., Danner, S. A. et al. (2001). Limited patient adherence to highly active antiretroviral therapy for HIV-1 infection in an observational cohort study. Arch.Intern.Med., 161, 1962-1968.

Oette, M., Kroidl, A., Gobels, K., Stabbert, A., Menge, M., Sagir, A. et al. (2006). Predictors of short-term success of antiretroviral therapy in HIV infection. J.Antimicrob.Chemother., 58, 147-153.

Parienti, J. J., Verdon, R., Bazin, C., Bouvet, E., Massari, V., \& Larouze, B. (2001). The pills identification test: a tool to assess adherence to antiretroviral therapy. JAMA, 285, 412.

Park, W. B., Choe, P. G., Kim, S. H., Jo, J. H., Bang, J. H., Kim, H. B. et al. (2007). One-year adherence to clinic visits after highly active antiretroviral therapy: a predictor of clinical progress in HIV patients. J.Intern.Med., 261, 268-275.

Paterson, D. L., Swindells, S., Mohr, J., Brester, M., Vergis, E. N., Squier, C. et al. (2000). Adherence to protease inhibitor therapy and outcomes in patients with HIV infection. Ann.Intern.Med., 133, 21-30.

Saul, J., Erwin, J., Sabin, C. A., Kulasegaram, R., \& Peters, B. S. (2001). The relationships between ethnicity, sex, risk group, and virus load in human immunodeficiency virus type 1 antiretroviral-naive patients. J.Infect.Dis., 183, 1518-1521.

Schaeffeler, E., Eichelbaum, M., Brinkmann, U., Penger, A., Asante-Poku, S., Zanger, U. M. et al. (2001). Frequency of C3435T polymorphism of MDR1 gene in African people. Lancet, 358, 383-384.

Smith, P. R., Sarner, L., Murphy, M., James, B., Thomas, J. M., Skinner, C. J. et al. (2003). Ethnicity and discordance in plasma HIV-1 RNA viral load and CD4+ lymphocyte 
count in a cohort of HIV-1-infected individuals. J.Clin.Virol., 26, 101-107.

Stone, V. E., Hogan, J. W., Schuman, P., Rompalo, A. M., Howard, A. A., Korkontzelou, C. et al. (2001). Antiretroviral regimen complexity, self-reported adherence, and HIV patients' understanding of their regimens: survey of women in the her study. J.Acquir.Immune.Defic.Syndr., 28, 124-131.

van den Berg, J. B., Hak, E., Vervoort, S. C., Hoepelman, I. M., Boucher, C. A., Schuurman, R. et al. (2005). Increased risk of early virological failure in non-European HIV1-infected patients in a Dutch cohort on highly active antiretroviral therapy. HIV.Med., 6, 299-306.

van Sighem, A. I., van de Wiel, M. A., Ghani, A. C., Jambroes, M., Reiss, P., Gyssens, I. C. et al. (2003). Mortality and progression to AIDS after starting highly active antiretroviral therapy. AIDS, 17, 2227-2236.

Wolf, M. S., Davis, T. C., Arozullah, A., Penn, R., Arnold, C., Sugar, M. et al. (2005). Relation between literacy and HIV treatment knowledge among patients on HAART regimens. AIDS Care, 17, 863-873.

Yuan, Y., L'italien, G., Mukherjee, J., \& Iloeje, U. H. (2006). Determinants of discontinuation of initial highly active antiretroviral therapy regimens in a US HIV-infected patient cohort. HIV.Med., 7, 156-162. 
Table 1: Quantitative interview on adherence

\section{Regimen}

There is a lot of medication for HIV infection. Here you see all the pills which are prescribed to people with HIV infection. Can you tell which medication is prescribed to you?

How many of this medicine should you take?

How often should you take this medicine?

Burden/difficulty of the regimen?

Many people who use the same medication as you do, think it is difficult to take this medicine every day. How is this for you? Very difficult / difficult / neutral / easy / very easy

When someone says it is difficult: why is it difficult to take the medication? Anything else?

Do you have suggestions for other people who also find it difficult to take this medicine?

What could be in your opinion an important improvement in HIV medication, which makes it more easy for you or for other people to take the HIV medication? You can think of, for example, medicines with less side effects, medicine you have to take less frequently, smaller medicines or maybe other things?

Yesterday and the day before yesterday

We would like to know how people in daily life cope with taking the medicine.

Could you describe how yesterday passed by?

Yesterday was: Monday/Tuesday/Wednesday/Thursday/Friday/Saturday/Sunday

When taking the medication was not spontaneously mentioned: did the interviewee take the medication yesterday/? If "Yes", when, what and how many pills were taken?

Taking the medicine

Many people who use the same medication as you do, don't always take their medicine, for example because they forget, feel sick or ill, or because taking the medication can not be combined with their doings at that moment.

Does it ever happen to you that you don't take the medicine at all? Yes/No

How many days the past week you think you did not take all the medication?

Maybe you can remember when you did not take all the medicine?

Never/Days/Weeks/Months?

Stopping the medication

Some people stop for a while taking the medicine because they feel well, for example for a couple of days or weeks. Some people stop with taking all the medication, others with taking one or two medicines, and other people just take less medication than the prescribed amount. Do you ever stop medication or do you ever take less medication than prescribed when you feel well? If "Yes", what was the most important reason?

Some people stop for a while taking the medicine because they don't feel well, for example if they have side effects of the medication. Some people stop with taking all the medication, others with taking one or two medicines, and other people just take less medication than the 
prescribed amount.

Do you ever stop medication or do you ever take less medication than prescribed when you don't feel well? If Yes, what was the most important reason?

Time of medication taking

Many people who use the same medication as you do, take the medication sometimes later than prescribed.

Does it ever happen to you that you take the medication later than prescribed? Yes/No

How many days in the past week you think you took the medication later than prescribed?

Maybe you can remember when you took the medication later than prescribed? Never/Days/Weeks/Months

Appointments

People with HIV have to come to the hospital regularly for visits with their doctor. Because of this people do forget appointments once in a while.

Did this happen to you? Yes/No

How many times the past year? 
Table 2. Baseline characteristics of study population

\begin{tabular}{|c|c|c|c|c|}
\hline & & $\begin{array}{l}\text { Non-immigrants } \\
n=81\end{array}$ & $\begin{array}{l}\text { Immigrants } \\
\mathrm{n}=61\end{array}$ & p-value \\
\hline Male sex & & \begin{tabular}{|l|}
$56(69.1)$ \\
\end{tabular} & 11 (18.0) & $<0.01$ \\
\hline Age, years (IQR) & & $44(37-53)$ & $33(30-40)$ & $<0.01$ \\
\hline Transmission category & MSM & $48(59.3)$ & $4(6.6)$ & $<0.01$ \\
\hline & Heterosexual & $30(37.0)$ & $52(85.2)$ & \\
\hline & IDU & $1(1.2)$ & $0(0.0)$ & \\
\hline 28 & Other & $2(2.5)$ & $5(8.2)$ & \\
\hline CDC stage $\mathrm{C}$ & & $24(29.6)$ & $13(21.3)$ & 0.26 \\
\hline Nadir CD4 cell count, $10^{6} / \mathrm{L}$ (IQR) & & $140(35-275)$ & $150(60-230)$ & 0.92 \\
\hline Highest plasma HIV-1 RNA, copies/mL (IQR & & $\begin{array}{l}140.000 \quad(44.942- \\
420.435\end{array}$ & $\begin{array}{ll}76.015 & (17.952- \\
194.767 & \end{array}$ & $<0.01$ \\
\hline Time since HIV diagnosis and interview (yea & & $8.2(4.0-12.3)$ & $3.0(1.1-5.2)$ & $<0.0001$ \\
\hline Time since initiation of HAART and intervie & $N$ (years) & $5.3(2.9-7.4)$ & $2.0(0.7-3.3)$ & $<0.0001$ \\
\hline \multirow{4}{*}{$\begin{array}{l}\text { HAART regimen at the time } \\
\text { of the interview }\end{array}$} & PI containing & $32(39.5)$ & $25(41.0)$ & 0.47 \\
\hline & NNRTI & $47(58.0)$ & $36(59.0)$ & \\
\hline & PI+NNRTI & $0(0)$ & $0(0)$ & \\
\hline & Triple NRTI & $2(2.5)$ & $0(0)$ & \\
\hline \multirow{4}{*}{$\begin{array}{l}\text { Number of previous HAART regimens } \\
\text { including current one }(\mathrm{n}=137)\end{array}$} & 1 & $18(23.1)$ & 24 (40.7) & \multirow[t]{4}{*}{0.01} \\
\hline & 2 & $23(29.5)$ & $22(37.3)$ & \\
\hline & 3 & 15 (19.2) & $8(13.6)$ & \\
\hline & $>3$ & $22(28.2)$ & $5(8.5)$ & \\
\hline
\end{tabular}

Data are $\mathrm{n}(\%)$, unless otherwise stated.

IQR: Inter Quartile Range

HAART: Highly Active Antiretroviral Therapy 
MSM: men having sex with men

IDU: intravenous drug use 
Table 3: Surrogate markers of non-adherence in immigrant and in non- immigrant patients, and odds ratio of virological failure in non-adherent versus adherent patients.

\begin{tabular}{|c|c|c|c|c|c|c|}
\hline & $\begin{array}{l}\text { Non- } \\
\text { immigrants } \\
(\mathrm{n}=81)\end{array}$ & $\begin{array}{l}\text { Immigrants } \\
(\mathrm{n}=61)\end{array}$ & $\begin{array}{l}\text { Virological } \\
\text { failure in } \\
\text { adherent } \\
\text { patients (n, \%) }\end{array}$ & $\begin{array}{l}\text { Virological } \\
\text { failure in } \\
\text { nonadherent } \\
\text { patients (n, \%) }\end{array}$ & $\begin{array}{l}\text { OR } 1 \\
(95 \% \mathrm{CI}) \\
\text { p-value }\end{array}$ & $\begin{array}{l}\text { OR } 2 \\
(95 \% \mathrm{CI}) \\
\text { p-value }\end{array}$ \\
\hline $\begin{array}{l}\text { Incorrect knowledge of the regimen. } \\
(\mathrm{n}=136)\end{array}$ & $5 / 80(6.3)$ & $2 / 56(3.6)$ & $17 / 129(13.2)$ & $2 / 7(28.6)$ & $\begin{array}{l}0.6(0.1-3.0) \\
0.70 \\
\end{array}$ & $\begin{array}{l}2.6(0.5-14.7) \\
0.25 \\
\end{array}$ \\
\hline $\begin{array}{c}\text { Treatment perceived as very difficult, } \\
\text { difficult or neutral. }(\mathrm{n}=142)\end{array}$ & $16 / 81(19.8)$ & $22 / 61(36.1)$ & 16/104 (15.4) & $3 / 38(7.9)$ & $\begin{array}{l}2.3(1.1-4.9) \\
0.03\end{array}$ & $\begin{array}{l}0.5(0.1-1.7) \\
0.25\end{array}$ \\
\hline $\begin{array}{l}\text { Reporting to take medication too late } \\
\text { yesterday. }(\mathrm{n}=142)^{*}\end{array}$ & $8 / 81(9.9)$ & $3 / 61(4.9)$ & 19/131 (14.5) & $0 / 11(0)$ & $\begin{array}{l}0.5(0.1-1.9) \\
0.35 \\
\end{array}$ & $\begin{array}{l}0.3(0.0-4.4) \\
0.36 \\
\end{array}$ \\
\hline $\begin{array}{l}\text { Reporting to take medication too late } \\
\text { the day before yesterday. } \\
(\mathrm{n}=142)^{*}\end{array}$ & $12 / 81(14.8)$ & $2 / 61(3.3)$ & $19 / 128(14.8)$ & $0 / 14(0)$ & $\begin{array}{l}0.2(0.0-0.9) \\
0.02\end{array}$ & $\begin{array}{l}0.2(0.0-3.4) \\
0.22\end{array}$ \\
\hline $\begin{array}{c}\text { Reporting to miss medication. } \\
(\mathrm{n}=142)^{*}\end{array}$ & $24 / 81(29.6)$ & $18 / 61(29.5)$ & 15/100 (15.0) & $4 / 42(9.5)$ & $\begin{array}{l}1.0(0.5-2.1) \\
0.99\end{array}$ & $\begin{array}{l}0.6(0.2-1.9) \\
0.38 \\
\end{array}$ \\
\hline $\begin{array}{c}\text { Reporting to stop medication when } \\
\text { feeling well. }(\mathrm{n}=141)^{*}\end{array}$ & $1 / 81(1.2)$ & $2 / 60(3.3)$ & 17/138 (12.3) & $1 / 3(33.3)$ & $\begin{array}{l}2.8(0.2-31.2) \\
0.58\end{array}$ & $\begin{array}{l}3.6(0.3-41.4) \\
0.34 \\
\end{array}$ \\
\hline $\begin{array}{l}\text { Reporting to stop medication when not } \\
\text { feeling well. }(\mathrm{n}=140)^{*}\end{array}$ & $2 / 81(2.5)$ & $3 / 59(5.1)$ & 15/135 (11.1) & $3 / 5(60.0)$ & $\begin{array}{l}2.1(0.3-13.1) \\
0.65\end{array}$ & $\begin{array}{l}12(1.9-77.7) \\
0.02\end{array}$ \\
\hline $\begin{array}{l}\text { Reporting to take the medication later } \\
\text { than prescribed. }(\mathrm{n}=141)^{*}\end{array}$ & $48 / 80(60.0)$ & $33 / 61(54.1)$ & $6 / 60(10.0)$ & $13 / 81(16.0)$ & $\begin{array}{l}0.8(0.4-1.5) \\
0.48\end{array}$ & $\begin{array}{l}1.7(0.6-4.8) \\
0.30\end{array}$ \\
\hline $\begin{array}{c}\text { Non-adherent as assessed by Global } \\
\text { adherence score }(\mathrm{n}=141)^{\mathrm{a}}\end{array}$ & $58 / 80(72.5)$ & $38 / 61(62.3)$ & $4 / 45(8.9)$ & $15 / 96(15.6)$ & $\begin{array}{l}0.6(0.3-1.3) \\
0.19\end{array}$ & $\begin{array}{l}1.9(0.6-6.1) \\
0.26 \\
\end{array}$ \\
\hline $\begin{array}{l}\text { Self Report of missing clinic visits in } \\
\text { the last year. }(\mathrm{n}=140)\end{array}$ & $11 / 81(13.6)$ & $11 / 59(18.6)$ & $15 / 118(12.7)$ & $4 / 22(18.2)$ & $\begin{array}{l}0.8(0.4-1.5) \\
0.48\end{array}$ & $\begin{array}{l}1.5(0.5-5.1) \\
0.50\end{array}$ \\
\hline $\begin{array}{l}\text { Missed visits according the hospital } \\
\text { registration system. }(n=140)\end{array}$ & $25 / 79(31.6)$ & $30 / 61(49.2)$ & $11 / 85(12.9)$ & $8 / 55(14.5)$ & $\begin{array}{l}2.1(1.0-4.1) \\
0.04\end{array}$ & $\begin{array}{l}1.1(0.4-3.1) \\
0.79\end{array}$ \\
\hline $\begin{array}{l}\text { Plasma drug levels compatible with } \\
\text { non-adherence. }(\mathrm{n}=136)\end{array}$ & $3 / 75(4.0)$ & 7/61 (11.5) & $17 / 126(13.5)$ & $2 / 10(20.0)$ & $\begin{array}{l}3.1(0.8-12.6) \\
0.11\end{array}$ & $\begin{array}{l}1.6(0.3-8.2) \\
0.63\end{array}$ \\
\hline $\begin{array}{l}\text { Dispensed } \quad \text { Medication/Prescribed } \\
\text { Medication }<85 \% \text {. }(\mathrm{n}=115)\end{array}$ & $25 / 68(36.8)$ & $13 / 47(27.7)$ & $7 / 77(9.1)$ & $8 / 38(21.1)$ & $\begin{array}{l}0.7(0.3-1.5) \\
0.31\end{array}$ & $\begin{array}{l}2.7(0.9-8.0) \\
0.09\end{array}$ \\
\hline
\end{tabular}

\section{Data are $\mathrm{n}(\%)$}


${ }^{\text {a }}$ Global adherence score: patients were classified as non-adherent when one or more answer(s) on one of the questions with an asterisk was non-adherent.

*: used in the combined adherence score

OR 1: Non-adherence in immigrant versus non-immigrant patients

OR 2: Virological failure in non-adherent versus adherent patients 